\title{
PENGGUNAAN BALOK ANGKA SEBAGAI MEDIA PEMBELAJARAN \\ UNTUK MENINGKATKAN KEMAMPUAN KOGNITIF ANAK DI \\ TAMAN KANAK-KANAK PERTIWI KOTA JAMBI
}

\author{
Ade Hasendra \\ TK Islam Al Falah Kota Jambi \\ Email: ade_hasendra@yahoo.co.id
}

\section{A. PENDAHULUAN}

\section{Latar Belakang}

Anak usia dini adalah salah satu pewaris dari pada setiap bangsa, Anak merupakan aset bangsa, sebagai pewaris dan sekaligus sebagai generasi pelangsung cita-cita perjuangan bangsa. Mereka perlu dipersiapkan demi kelangsungan eksistensi bangsa dan negara di masa mendatang. Oleh sebab itulah perlu dipersiapkan agar anak dapat tumbuh dan berkembang dengan sebaikbaiknya sehingga kelak menjadi orang dewasa yang sehat, baik secara fisik, mental, maupun sosial-emosionalnya. Untuk mencapai hal itu harus ada upaya pengembangan potensi yang dimilikinya secara optimal agar menjadi sumber daya manusia yang berkualitas di masa depan.

Secara kuantitatif jumlah anak usia dini di Indonesia sangat besar. Mereka merupakan generasi penerus bangsa yang harus mendapat perhatian serius. Kesadaran dan komitmen terhadap perkembangan yang terjadi pada anak usia dini harus menjadi pokok pikiran kita bersama, hal ini tentu tak lepas dari peran orang tua, guru, lingkungan sekitar anak.

Pada saat ini Taman kanak - kanak yaitu jenjang pendidikan anak usia dini telah menjadi sebuah jalur formal bagi anak untuk mengembangkan setiap aspek kepribadiannya baik dari perkembangan bahasa anak, motorik halus, motorik kasar, kognitif, sains dan lainnya lagi, hal ini tentu membuat kita menyadari bahwa pendidikan itu tak hanya dimulai dari Sekolah Dasar tapi dari sejak anak dilahirkan di dunia ini.

Upaya peningkatan kualitas pendidik tentunya akan menyebabkan meningkat pula kualitas peserta didiknya, hal ini dikarenakan pendidikan anak 
usia dini menitikberatkan peletakan dasar pertumbuhan serta perkembangan fisik, kecerdasan, sosial emosional, bahasa dan komunikasi.

Salah satu perkembangan yang harus berada pada anak adalah perkembangan kognitif, yaitu kemampuan untuk menghubungkan, menilai, dan mempertimbangkan suatu kejadian atau peristiwa. Proses kognitif berhubungan dengan tingkat kecerdasan (inteligensi) yang menandai seorang dengan berbagai minat terutama sekali ditujukan kepada ide-ide dan belajar. Perkembangan kognitif juga dimaksudkan agar anak mampu melakukan ekplorasi terhadap dunia sekitar melalui panca indranya. Dengan pengetahuan yang diperolehnya, anak akan dapat melangsungkan hidupnya dan menjadi manusia yang utuh sesuai dengan kodratnya sebagai makhluk tuhan yang harus memberdayakan apa yang ada di dunia ini untuk kepentingan dirinya dan orang lain.

Kemampuan kognitif sangat diperlukan peserta didik dalam pendidikan. Perkembangan kognitif merupakan salah satu aspek yang sangat penting dalam perkembangan peserta didik. Kita ketahui bahwa peserta didik merupakan objek yang berkaitan langsung dengan proses pembelajaran, sehingga perkembangan kognitif sangat menentukan keberhasilan peserta didik dalam sekolah. Dalam perkembangan kognitif di sekolah, guru sebagai tenaga kependidikan yang bertanggung jawab dalam melaksanakan interaksi edukatif dan pengembangan kognitif peserta didik, perlu memiliki pemahaman yang sangat mendalam tentang perkembangan kognitif pada anak didiknya.

Dari hasil observasi kendala yang sering terjadi di TK Pertiwi Kota Jambipeneliti menemukan beberapa masalah yang berkaitan dengan perkembangan kognitif anak. Pada umumnya masalah yang dialami anak usia Taman Kanak-kanak berawal dari ketidakmampuan menangkap dan memahami dengan baik dikarenakan kurangnya konsentasi atau pemusatan perhatian anak, hal ini ditandai dengan adanya beberapa kondisi berikut. Pertama, disaat proses belajar anak melakukan aktivitas fisik yang berlebihan. Kedua, anak kesulitan ketika melaksanakan tugas-tugas yang membutuhkan ketekunan berkesinambungan, sehingga anak cenderung kepada menghindari dan menolak 
melakukan kegiatan tersebut. Ketiga, anak sulit untuk mempertahankan pusat perhatian pada waktu bermain ( perhatian anak mudah teralihkan ).

Mengingat masalah diatas, apabila tidak segera diatasi maka akan berkibat munculnya masalah-masalah baru seperti anak akan semakin kesulitan menerima materi berikutnya, dan sangat mempengaruhi kemampuan berpikir anak pada tahap perkembangan selanjutnya yang bisa dimungkinkan juga mempengaruhi hubungan sosial anak dengan orang lain.

Dalam usaha menanggulangi masalah tersebut, mendorong peneliti untuk melakukan penelitian terhadap minat dan reaksi anak dengan media pembelajaran menggunakan balok angka.

Selain hal itu tentunya peneliti melakukan proses tanya jawab interaktif yang memungkinkan anak untuk mengembangkan imajenasinya pula sehingga peneliti berharap menghasilkan pembelajaran yang efektif, berkualitas, dan menarik minat anak untuk mengikuti pembelajaran sehingga perkembangan yang ingin dicapai dapat terlaksana sesuai harapan.

\section{Perumusan Masalah}

Berdasarkan latar belakang masalah di atas, maka yang menjadi rumusan masalah dalam penelitian ini adalah sebagai berikut:

1. Apakah metode bermain balok angka dapat meningkatkan kemampuan kognitif anak di TK Pertiwi Kota Jambi?

2. Apakah metode bermain balok angka dapat menarik minat dan meningkatkan konsentrasi anak selama kegiatan berlangsung?

\section{Tujuan Penelitian}

Berdasarkan rumusan masalah di atas maka tujuan diadakannya penelitian ini adalah untuk:

1. Untuk mengetahui peningkatan kemampuan kognitif anak dengan metode bermain menggunakan balok angkaTK Pertiwi Kota Jambi.

2. Untuk Mengetahui peningkatan minat dan konsentrasi anakdengan metode permainan balok angka diTK Pertiwi Kota Jambi. 


\section{Manfaat Penelitian}

a) Sebagai masukan bagi pihak TK Pertiwi dalam memberikan media informasi kepada guru, sehingga menjadikan guru dapat mengembangkan dan membuat inovasi dan kreatifitas pembelajaran yang lebih meningkatkan hasil belajar.

b) Bagi peneliti diharapkan penelitian ini dapat bermanfaat sebagai cara mengamalkan ilmu serta memberikan pengetahuan kepada peneliti tentang pemanfaatan dan penggunaan media pendidikan yang dapat menarik minat anak.

c) Diharapkan penelitian ini dapat dijadikan referensi bagi peneliti lain yang akan mengangkat tema yang sama namun dengan sudut pandang yang berbeda.

d) Hasil dari perbaikan ini di harapkan dapat bermanfaat dan membantu pengembangan dan pola pembelajaran terutama bagi anak yang memiliki masalah dengan kemampuan bahasanya.

\section{B. KAJIAN TEORI}

\section{Pengertian Kognitif}

Kognitif adalah suatu proses berpikir, yaitu kemampuan individu untuk menghubungkan, menilai dan mempertimbangkan suatu kejadian atau peristiwa. Proses kognitif berhubungan dengan tingkat kecerdasan (intelegensi) yang menandai seseorang dengan berbagai minat terutama sekali ditujukan kepada ideide dan belajar.

Pembelajaran kognitif yang diterapkan pada anak harus diajarkan melalui bahasa sehari-hari dengan contoh yang ada pada kehidupan sehari-hari. Hal tersebut dimaksudkan agar anak dapat memahami konsep-konsep menjadi sesuatu yang konkret dan nyata. Anak pun harus diberi pemahaman melalui peragaan langsung yang dikemas melalui bermain agar pembelajaran lebih bermakna.

Sementara Piaget menyatakan bahwa cara berfikir anak bukan hanya kurang matang dibandingkan dengan orang dewasa karena kalah pengetahuan, tetapi juga berbeda secara kualitatif. Menurut penelitiannya juga bahwa tahap- 
tahap perkembangan intelektual individu serta perubahan umur sangat mempengaruhi kemampuan individu mengamati ilmu pengetahuan. (Laura A. King:152). Piaget mengemukakan penjelasan struktur kognitif tentang bagaimana anak mengembangkan konsep dunia di sekitar mereka. ( Loward s. Friedman and Miriam. W. Schustack. 2006: 59). Teori Piaget sering disebut genetic epistimologi (epistimologi genetik) karena teori ini berusaha melacak perkembangan kemampuan intelektual, bahwa genetic mengacu pada pertumbuhan developmental bukan warisan biologis (keturunan). (B.R. Hergenhahn \& Matthew H. Olson, 2010: 325).

Kemudian menurut Sary (2015 : 68) Kognitif adalah bagaimana cara individu bertingkah laku, cara individu bertindak, yaitu cepat lambatnya individu didalam memecahkan suatu masalah yang dihadapinya. Gambaran yang diberikan Williams tentang ciri-ciri perilaku kognitif adalah :

1. Berpikir lancar, yaitu menghasilkan banyak gagasan atau jawaban yang relevan dan arus pemikiran lancar.

2. Berpikir luwes, yaitu menghasilkan gagasan-gagasan yang beragam, mampu mengubah cara atau pendekatan dan arah pemikiran yang berbedabeda.

3. Berpikir orisinal, yaitu memberikan jawaban yang tidak lazim atau lain dari yang lain yang jarang diberikan kebanyakan orang lain.

4. Berpikir terperinci (elaborasi), yaitu mengembangkan, menambah, memperkaya suatu gagasan, memerinci detail-detail, dan memperluas suatu gagasan.

Anak yang proses berpikirnya berkembang dengan cepat dan baik sejalan dengan kehidupannya yang akan berkembang dengan baik dan optimal pula. Proses berpikir anak dapat dilihat dari bagaimana cara mereka dalam bertindak, mengatasi suatu situasi dalam memecahkan masalah, serta bagaimana sikap anak dalam mengambil keputusan. Kemudian menurut Sary (2015 : 68) kognitif berkaitan dengan memori dan intelegensi yang akan mengalami kemerosotan dengan terus bertambahnya usia. 
Bahkan kesimpulan usia terkait dengan penurunan proses kognitif ini tercermin dalam masyarakat ilmiah. Akan tetapi berdasarkan sejumlah hasil penelitian menunjukkan bahwa terjadinya kemerosotan proses kognitif dengan penurunan kemampuan fisik sebenarnya hanya salah satu stereotip budaya yang meresap dalam diri manusia.

Kognitif akan berkembang lebih optimal dalam kehidupan seseorang sejalan dengan tumbuh kembangnya. Dalam segala aktivitasnya, seseorang dapat beraktivitas dengan baik dan optimal juga. Bukan berarti semakin dengan bertambahnya usiaseseorang, maka semakin menurun pula perkembangan kognitifnya. Semakin bertambahnya usia seseorang, maka akan berkembang pula kognitifnya jika terus tetap belajar, menggali potensi yang ada dalam dirinya, serta mencari pengetahuan-pengetahuan baru.

Ranah kognitif mencakup kegiatan mental (otak). Segala upaya yang menyangkut aktivitas otak adalah termasuk dalam ranah kognitif. Ranah kognitif memiliki enam jenjang atau aspek, yaitu:

1. Pengetahuan/hafalan/ingatan (knowledge)

2. Pemahaman (comprehension)

3. Penerapan (application)

4. Analisis (analysis)

5. Sintesis (syntesis)

6. Penilaian/penghargaan/evaluasi (evaluation)

\section{Balok Angka}

Balok adalah bangun ruang tiga dimensi yang dibentuk oleh tiga pasang persegi atau persegi panjang, dengan paling tidak satu pasang diantaranya berukuran berbeda. Balok memiliki 6 sisi, 12 rusuk dan 8 titik sudut. Atau dapat juga dikatakan suatu bangun ruang yang dibatasi oleh 6 persegi panjang dimana setiap sisi persegi panjang berhimpit dengan tepat satu sisi persegi panjang yang lain dan persegi panjang yang sehadap adalah kongruen.

Sedangkan balok angka adalah bangun ruang yang di sisinya terdapat angka - angka yang biasa digunakan untuk media pembelajaran anak di tingkat PAUD. 


\section{Anak Usia Dini}

Anak usia dini adalah anak yang baru lahir sampai 6 tahun, anak usia TK atau prasekolah termasuk dalam usia dini yaitu usia $4-6$ tahun. Perkembangan kecerdasan pada masa ini mengalami peningkatan dari $50 \%$ menjadi $80 \%$, dan usia 4 - 6 tahun, merupakan masa peka bagi anak. Anak mulai sensitif untuk menerima berbagai upaya perkembangan seluruh potensi anak.

Masa peka adalah masa terjadinya pematangan fungsi - fungsi fisik dan psikis yang siap merespon stimulasi yang diberikan oleh lingkungan, dan masa terpenting untuk sebuah pendidikan adalah masa kanak - kanak, yang merupakan masa terpanjang dalam kehidupan manusia.

Era globalisasi menuntut dipersiapkannya individu dengan ciri pribadi unggul yang memberikan berbagai macam ransangan mental yang kaya sejak usia dini. Ciri pirbadi yang unggul yaitu cerdas, kreatif, dan disiplin. Juga memiliki sifat bagaimana tertuang dalam Astra Citra Anak Indonesia : iman dan taqwa, hormat kepada orang tua, jujur, optimis, cinta tanah air dan sebagainya.

Hal ini bisa terwujud apabila sejak usia dini justru tetap berada dalam kodratnya sebagai anak - anak yang tidak terlepas dari bermain. Bermain sebagai salah satu hak anak yang paling hakiki, untuk itu bermain perlu memperoleh porsi yang cukup menonjol pada pelaksanaannya PKB Prasekolah saat ini. Selama periode masa kanak - kanak ini, anak berhubungan dengan suatu kelompok sosial, dan dengan lingkungan serta benda - benda yang ada dirumah semuanya dapat diperalat untuk menggerakan kecerdasan anak.

Pertumbuhan terjadi secara simultan dengan perkembangan, sehingga pada anak - anak proses tersebut dikenal dengan sebutan tumbuh kembang anak. Proses tumbuh kembang anak berlangsung secara teratur, saling berkaitan dan saling berkesinambungan, proses tumbuh kembang anak terbagi ke dalam 3 periode, yaitu masa zigot, masa embrio, masa janin / fatus.

Kemampuan kinerja otak sangat ditentukan oleh jumlah sel - sel syaraf dan jumlah hubungan antar sel syaraf otak. Pertumbuhan dan perkembangan sel syaraf otak saat pralahir sangat dipengaruhi oleh faktor genetis dan asupan gizi. 
Makanan bergizi diperlukan tubuh agar sel syaraf otak dapat tumbuh kembang secara optimal.

\section{METODE PENELITIAN}

\section{Desain Penelitian}

Penelitian ini merupakan Penelitian Tindakan Kelas (PTK) atau Classroom Action Research (CAR).

\section{Prosedur Penelitian}

Penelitian ini direncanakan dengan 3 siklus dengan tahapan seperti berikut:

a. Perencanaan Tindakan

b. Pelaksanaan Tindakan

c. Observasi

d. Refleksi

\section{Lokasi dan Subjek Penelitian}

Penelitian ini dilakukan di TK Pertiwi Kota Jambi yang beralamat di Jln. Hos Cokroaminoto Kec. Danau Sipin Kota Jambi

Berdasarkan data yang ada, ditemukan karakteristik anak TK Pertiwi Kota Jambi Sebagai berikut :

1. 8 orang pekerjaan orang tuanya adalah swasta

2. 7 orang pekerjaan orang tuanya adalah PNS

3. 8 orang pekerjaan orang tuanya adalah dagang

\section{Teknik Pengumpulan Data}

- Observasi/Pengamatan

- Wawancara

- Dokumentasi

\section{Teknik Pengolahan Data}

Perolehan data hasil belajar bercerita menggunakan teknologi multimedia dengan tema binatang kemudian dirata-ratakan, dihitung dan dipersentasekan. Untuk memperoleh hasil belajar melalui pengamatan ketercapaian indikatorindikator, di TK PertiwiKota Jambikota Jambi mempunyai standar penilaian. 
Berikut kategori dalam penilaian di TK Pertiwi Kota Jambi:

Tabel 1. Standar penilaian dan Kategorinya

\begin{tabular}{|l|c|l|}
\hline No. & Catatan Penilaian & \multicolumn{1}{|c|}{ Kategori } \\
\hline 1 & MB & Mulai berkembang \\
2 & BSH & Berkembang sesuai Haraan \\
3 & BSB & Berkembang sangat baik \\
\hline
\end{tabular}

\section{B. Teknik Analisis Data}

Analisis data dilakukan secara bertahap selama penelitian, pada akhir pertemuan diadakan analisa data secara keseluruhan. Dari analisis data diperoleh sebuah kesimpulan yang dapat menjawab permasalahan, data tersebut kemudian dianalisis, diolah dan dideskripsikan. Dari data skor yang terkumpul, dihitung skor rata-rata kelas, yang berfungsi untuk melihat perkembangan skor secara keseluruhan. Teknik analisis data yang digunakan selain analisis deskripsi pengamatan juga digunakan analisis data kuantitatif yang berfungsi untuk mengetahui pemerataan skor peserta didik, dengan menggunakan rumus sebagai berikut :

$$
\mathrm{NR}=\frac{\sum \mathrm{NA}}{\mathrm{SN}}
$$

Keterangan :

$$
\begin{aligned}
& \text { NR = Nilai Rata-rata } \\
& \text { NA = Nilai Akhir } \\
& \text { SN = Jumlah siswa }
\end{aligned}
$$

\section{HASIL PENELITIAN DAN PEMBAHASAN}

\section{Hasil Penelitian}

\section{- Siklus I}

Pada Siklus I anak masih terlihat ragu-ragu dan kebingungan dalam melaksanakan kegiatan inti satu hari. Pada kegiatan ini pun belum terlihat perkembangan anak masih lebih banyak bermain dengan temannya, mungkin hal 
ini dikarenakan peneliti yang kurang mensosialisasikan bentuk kegiatan kepada anak.

Objek penelitian sebanyak 23 anak dalam pelaksanaan pembelajaran iniaktivitas dan hasil belajar anak belum maksimal, sehingga pelaksanaan kegiatanupaya meningkatkan kemampuan kognitif anak melalui permainan balok angkabelum dilakukan dengan maksimal. Dikarenakandalam penyajian materi guru belum bisa menguasai kelas dengan baik, guru juga kurang mensosialisasikan bentuk dari pembelajaran kepada anak.

Dalam hal ini guru dianjurkan untuk melakukan adaptasi terlebih dahulu dengan metode pembelajaran yang diterapkan, sehingga anak tidak merasa ragu ragu untuk melakukan kegiatan, serta guru harus mampu menguasai kelas dengan manajemen waktu yang baik pula.

Untuk selanjutnya di siklus kedua guru akan mencoba membuat anak untuk lebih memahami metode pembelajaran menggunakan permainan balok anngka, serta guru juga lebih aktif untuk membuat pembelajaran jadi menarik.

\section{- Siklus II}

Pada siklus kedua peneliti mencoba membagi anak untuk mengerjakan tugas dalam beberapa kelompok dan terlihat bahwa anak telah mampu untuk bekerja secara kelompok untuk menyelesaikan tugas Balok Angka, hal itu diketahui dari anak yang telah berhasil mengerjakan tugas yang di berikan oleh guru dengan baik dan benar, penelitijuga mencoba untuk merubah pola belajar dengan melakukan setting tempat serta mensosialisasikan kembali Bermain Balok Angka

Dalam siklus penelitian kedua ini hampir sama dengan siklus penelitian pertama peneliti selain sebagai subjek penelitian juga sebagai objek penelitian, yang dibantu oleh guru lain. Adapun yang perlu dipahami dan disiapkan adalah tema yang digunakan yaitu pekerjaan, alat dan bahan untuk pembelajaran di siklus II ini dipersiapkan dengan baik seperti bentuk gambar dari jenis - jenis pekerjaan, balok angka yang lebih variatif.

Perkembangan kognitif anak pada siklus II ini mengalami peningkatan walaupun target penelitian belum tercapai. Hal ini ditunjukkan dengan 
perkembangan kognitif anak sesuai dengan indikator perkembangan yang telah ditetapkan pada umumnya belum berkembang secara optimal. Ketercapaian perkembangan kognitif anak yang belum optimal pada indikator mengenal sebab akibat siklus pertanian, membedakan ukuran berat ringan dan mencocokan bilangan dengan lambang bilangan.

\section{- Siklus III}

Dalam siklus penelitian ketiga ini peneliti lebih memperhatikan lagi detail dari pelajaran yang akan di sampaikan dan juga peneliti menyediakan alat peraga untuk masing-masing anak, sehingga hasil penilaian yang di dapatkan nanti lebih spesifik

Tema yang digunakan pada kegiatan ini masih sama dengan tema pada kegiatan sebelumnya yaitu pekerjaan dengan sub tema pertukangan.

Untuk perencanaan di siklus penelitian ketiga ini anak diminta untuk membuat bentuk menara menggunakan balok angka sesuai urutan dengan tahapan: Guru mengajak anak untuk berhitung angka 1 sampai dengan 10 secara bersama - sama, masing - masing anak diberikan alat peraga balok angka dengan posisi acak, anak diminta berlomba menyusun balok angka sesuai urutan dari yang terkecil di bawah.

Setelah melaksanakan kegiatan pembelajaran siklus III, peneliti melakukan refleksi berdasarkan hasil observasi aktivitas anak selama proses pembelajaran berlangsung untuk mengetahui sejauh mana keberhasilan pembelajaran menggunakan media bermain memancing. Hasil refleksi siklus III terlihat kegiatan pembelajaran siklus III menunjukkan keadaan yang lebih baik, lebih lancar sesuai rencana dan suasana kelas lebih kondusif, anak terlihat lebih aktif dan tertib, tidak ada anak bermain sendiri, berbicara dengan teman, menganggu teman saat mengikuti proses kegiatan pembelajaran menggunakan media bermain memancing. 


\section{Pembahasan}

\section{Peningkatan Kemampuan Bahasa Anak-Anak TK Pertiwi Kota Jambi} Kelompok B Pada Kegiatan Bercerita Menggunakan Teknologi Multimedia Dengan Tema Binatang

Pembahasan hasil penelitian didasarkan atas hasil pengamatan dan hasil nilai tugas anak setelah akhir pembelajaran pada bahasan alat transportasi kelas TK Pertiwi Kota Jambi pada siklus I, siklus II, dan siklus III yang dilanjutkan dengan refleksi tindakan pada setiap siklusnya. Penelitian dengan metode permainan balok angka pada tema pekerjaan ini dimaksudkan untuk mengatasi masalah yang dihadapi anak dan guru dalam kegiatan belajar mengajar yaitu rendahnya komunikasi interaktif yang menarik minat anak sehingga mengganggu perkembangan kognitif pada anak didik.

Penggunaan balok angka pada pembelajaran di Taman kanak - kanak umumnya sudah lazim dilakukan, namun biasanya kegiatan yang dilakukan dengan balok angka tidak di improvisasi sehingga anak terkadang merasa bosan dengan kegiatan. Pada umumnya kegiatan bermain balok angka hanya dalam bentuk menyusun kembali balok angka ke keadaan semula di mulai dari angka terkecil, namun disini peneliti mencoba untuk meminta anak lebih imajenatif lagi dalam mengurutkan bilangan angka dimana anak diminta untuk mengurutkan angka dalam bentuk tertentu seperti membuat gedung, atau membuat petak sawah.

Pengamatan pada siklus I didapatkan hasil temuan sebagai berikut, proses pembelajaran kegiatan bercerita menggunakan media permainan balok angka masih belum optimal, dari segi persiapan guru dan anak, metode permainan yang diberikan oleh guru dirasa kurang menarik, serta penguasaan kelas dan efisiensi waktu masih kurang optimal, kondisi ini dapat dilihat dari aktivitas anak pada siklus I yang hanya 52\% anak yang mengikuti kegiatan dengan baik. Dalam hal ini masih belum sesuai dengan kriteria yang diharapkan, dan aktivitas anak di dalam kelas perlu ditingkatkan lagi. Pada pengamatan disiklus II didapatkan hasil temuan yang meningkat dibandingkan pada siklus I, dilihat dari respond dan perhatian anak pada siklus II yang sudah mulai berinteraksi pada kegiatan yang dilakukan, anak pun sudah mulai komunikatif dan berani mengeluarkan 
pendapatnya pada kegiatan berkelompok, hal ini tentu menjadi perkembangan yang baik bagi guru sebagai peneliti dengan metode pembelajarannya, serta hal yang baik pula bagi perkembangan kognitif. Nilaikeberhasilan pada tahap ini mencapai 74\% ini meningkat dan sesuai dengan kriteria yang diharapkan.

Peningkatan aktivitas dikelas ini berlanjut pada tahap siklus selanjutnya. Pada pengamatan siklus terakhir yakni siklus III tingkatkeberhasilan sudah mencapai 86\%. Ini berarti perkembangan kognitif anak dirasakan sudah ada peningkatan di setiap perserta didik.

Pada pelaksanaannya dapat peneliti simpulkan bahwa peneliti telah dapat menguasai cara pengajaran yang baik dan mampu menarik minat anak untuk belajar terbukti dengan hasil evaluasi yang peneliti lakukan meningkatnya nilai anak.

Dari indikator-indikator yang sudah ditentukan berikut gambaran presentasi keberhasilan aktivitas anak TK Pertiwi Kota Jambi selama tiga siklus:

Penggunaan media permainan balok angka pada siklus I, siklus II dan III di TK Pertiwi Kota Jambi, peningkatan kemampuan kognitif anak dapat dilihat pada tabel 1.1 berikut :

Tabel 1.1 Rekapitulasi peningkatan kemampuan kognitif anak pada kegiatan bermain Balok Angka

\begin{tabular}{|l|l|c|c|c|}
\hline No. & \multicolumn{1}{|c|}{ Aspek } & Siklus I & Siklus II & Siklus III \\
\hline 1. & $\begin{array}{l}\text { Kemampuan anak dalam memahami } \\
\text { materi kegiatan }\end{array}$ & $45 \%$ & $65 \%$ & $89 \%$ \\
\hline 2. & $\begin{array}{l}\text { Kemampuan anak mengingat / } \\
\text { mencari objek yang benar }\end{array}$ & $50 \%$ & $75 \%$ & $91 \%$ \\
\hline 3. & $\begin{array}{l}\text { Konsentrasi dan ketepatan anak } \\
\text { dalam menarik garis ke tujuan }\end{array}$ & $52 \%$ & $78 \%$ & $83 \%$ \\
\hline 4. & $\begin{array}{l}\text { Pemahaman anak dalam mengikuti } \\
\text { perintah/arahan dari guru }\end{array}$ & $60 \%$ & $77 \%$ & $87 \%$ \\
\hline 5. & $\begin{array}{l}\text { Kemampuan anak dalam mengolah } \\
\text { informasi yang diterimanya }\end{array}$ & $53 \%$ & $69 \%$ & $86 \%$ \\
\hline 6. & Ketertarikan anak mengikuti kegiatan & $60 \%$ & $85 \%$ & $83 \%$ \\
\hline
\end{tabular}




\begin{tabular}{|c|l|c|c|c|}
\hline 7. & $\begin{array}{l}\text { Kesabaran anak dalam melaksanakan } \\
\text { kegiatan Balok Angka }\end{array}$ & $50 \%$ & $73 \%$ & $89 \%$ \\
\hline Rata - rata & $\mathbf{5 2 , 8 5 \%}$ & $\mathbf{7 4 , 5 7 \%}$ & $\mathbf{8 6 , 8 5 \%}$ \\
\hline
\end{tabular}

Tabel 1.1 menunjukan peningkatan yang sangat signifikan bagi perkembangan anak, hal ini dapat dilihat dari Siklus I dengan nilai rata - rata $52,85 \%$ meningkat pada siklus II dengan rata - rata 74,57\% dan peningkatan ini meningkat pesat pada akhir siklus III 86,85\%. Data tabel 1.1 dapat divisualisasikan pada diagaram batang berikut :

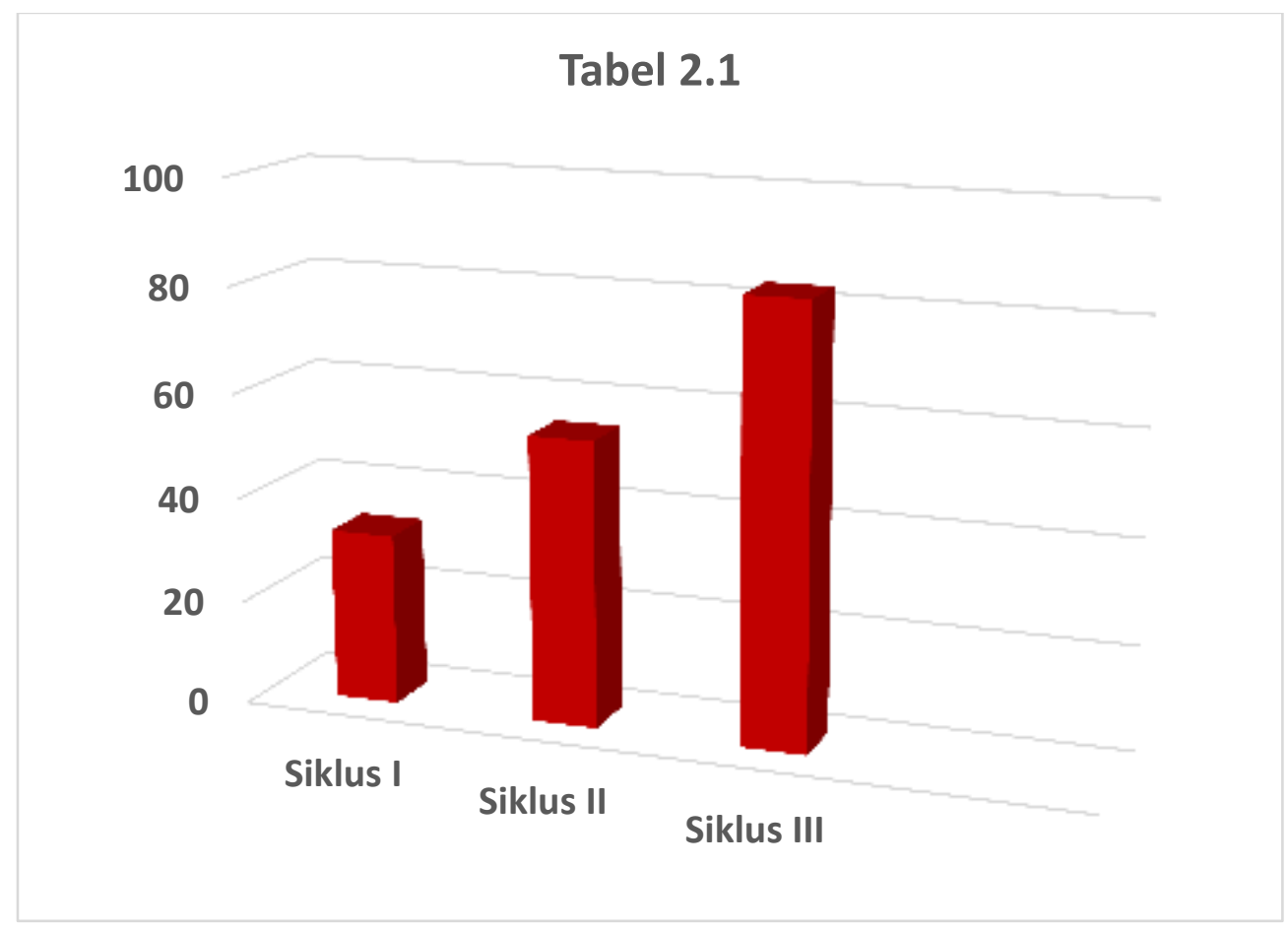

\section{Gambar 2.1 Peningkatan kemampuan kognitif anak pada kegiatan bermain}

\section{Balok Angka}

Dari tabel diatas kita dapat melihat bahwa terdapat perkembangan yang besar bagi perkembangan kognitif anak di di TK A, di mana pada saat sebelum peneliti melakukan tindakan nilai rata - rata anak hanya berada di 52,85\%, Dari kegiatan penggunaan media permainan balok angka pada siklus I dan siklus II di TK Pertiwi Kota Jambi Rata - rata perkembangan individu anak meningkat lebih dari 50\%, dari siklus I dengan nilai rata - rata 52,85\% meningkat pada siklus II 
dengan rata - rata 74,57\%, dan pada akhir siklus III nilai rata - rata anak $86,85 \%$. Hal ini membuktikan bahwa kegiatan bermain balok angka adalah permainan yang mempu mengembangkan aspek kognitif anak, namun untuk anak usia dini tentunya hal tersebut harus di dukung pula oleh peran guru dalam mengolah dan menyajikan kegiatan tersebut sehingga aspek perkembangan yang diinginkan tercapai

\section{Pengamatan Guru Dalam Proses Pembelajaran Kegiatan Bercerita Interaktif Menggunakan Teknologi Multimedia Pada TK Pertiwi Kota Jambi}

Guru sebagai pendidik dan orang tua asuh di kelas adalah orang yang paling tahudan merasakan apa yang terjadi di dalam kelas, apakah yang menjadi permasalah dan kelebihan - kelebihan apa yang dimiliki anak. Classroom action research (penelitiantindakan kelas) dapat dilakukan apabila seorang guru sejak awal menyadari bahwaada permasalahan yang terkait dengan proses dan hasil pembelajaran yang iarasakan di dalam kelas. Disamping itu, guru juga harus peka dengan metode pembelajaran yang di lakukannya apakah sudah mampu untuk menyelesaikan permasalah yang di hadapi anak atau tidak, kemudian guru perlu melakukan penelitian untuk memperoleh solusi yang paling tepat untuk mengatasi masalah yang terjadi didalam kelas.

Pada proses pra penelitian guru sudah mulai merasa peka dengan apa yang menjadi permasalah bagi anak, yaitu kurangnya pembelajaran interaktif yang dapat merangsang komunikasi antara guru dan anak terus berlanjut untuk jangka waktu yang lama, hal ini dikarenakan media yang sering digunakan oleh peneliti sebelumnya belum optimal dan cenderung membosankan bagi anak.

\section{E. KESIMPULAN DAN SARAN}

\section{Kesimpulan}

Proses pembelajaran menggunakan media bermain balok angka yaitu: (1) Guru berinteraksi untuk memperkenalkan konsep bilangan kepada anak, (2) Anak bermain balok angka, mengambil kartu angka untuk mencocokan bilangan dengan 
lambang bilangan. Pembelajaran melalui bermain balok angka akan : (a) pembelajaran yang menjemukan dan membosankan akan hilang, (b) anak terlibat secara langsung dan aktif menemukan pengalaman untuk mengintegrasikan dalam kehidupan nyata, (c) anak dapat melakukan percobaan, memahami sesuatu, membangun pengertian sendiri dan menemukan pengalaman yang bermakna, (d) mengenal hubungan sebab akibat, membedakan konsep berat ringan, mengklasifikasikan benda berdasarkan ukuran, mengenal konsep bilangan dan lambang bilangan.

Perkembangan kognitif anak di TK Pertiwi Kota Jambi dapat ditingkatkan melalui media bermain balok angka. Hal tersebut dapat dilihat dari peningkatan yang dialami dalam penelitian yang dilakukan peneliti dari sebelum tindakan, siklus I, siklus II dan siklus III

\section{Saran}

Berdasarkan kesimpulan dan pengalaman penulis selama melaksanakan kegiatan maka diajukan saran bahwa Guru TK diharapkan dapat terus mengikuti perkembangan dunia pendidikan anak untuk meningkatkan kualitas cara mendidik anak usia dini yang tepat dan efisien, guru diharapkan dapat menerapkan alternatif-alternatif pembelajaran yang menarik minat anak. Kegiatan bermain balok angka adalah salah satu dari proses kegiatan pengembangan yang dikemas menarik bagi anak usia dini, diharapkan pula guru dapat mengedepankan aspek permainan di setiap pembelajaran anak usia dini.

\section{DAFTAR PUSTAKA}

Paul Suparno. (2006) Perkembangan Kognitif Jean Piaget, Yogyakarta: Kanisius, Cet I

Direktorat Pendidikan Anak Usia Dini. (2003). Alat Permainan Edukatif untuk Kelompok Bermain. Jakarta: Depdiknas.

Hasan, Maimunah. (2009). PAUD (Pendidikan Anak Usia Dini)Jogjakarta: DIVA Press 
Latif, Mukhtar, dkk. (2013). Orientasi Baru Pendidikan Anak Usia Dini Teori dan Aplikasi. Jakarta: Kencana

Winda gunardi, Lilis suryani, Azizah Muis. (2011).Metode Pengembangan Perilaku dan Kemampuan Dasar Anak Usia Dini. Jakarta; Universitas Terbuka

Djam'an Satori, dkk. (2011). Profesi Keguruan. Jakarta; Universitas Terbuka Ahmad Susanto. (2011). Perkembangan Anak Usia Dini: Pengantar dalam Berbagai Aspeknya. Jakarta: Kencana Perdana Media Group.

Fatih Ali. (2014). Anak PAUD Bermain dan Belajar. Diakses dari http://www.mainan.web.id/2014/09/mainan-edukatif-Balok Angka.html.

Udin S. Winataputra, dkk. Teori Belajar dan Pembelajaran. Jakarta; Universitas Terbuka

Nana Syaodih Sukmadinata. (2013). Metode Pengajaran di Taman Kanak-Kanak. Jakarta: PT Rineka Cipta.

Badru Zaman. (2006). Pengembang Alat Permainan Edukatif Untuk Anak Taman Kanak-Kanak. Diakses: http://badruzaman.staf.upi.edu/files/2011/12/materi$\underline{\text { media-paud-upi.pdf }}$

Rika Ariyani, Editor Jurnal Literasiologi. Literasi Kita Indonesia. STAI Syekh Maulana Qori. Merangin Bangko. 